\title{
Sensitivity of understorey bird species in two different successional stages of the lowland Atlantic Forest, Brazil
}

\author{
ALAN LOURES-RIBEIRO ${ }^{1,2}$, MARCO A. MANHÃeS ${ }^{2}$ and MANOEL M. DIAS ${ }^{3}$ \\ ${ }^{1}$ Departamento de Sistemática e Ecologia, Centro de Ciências Exatas e da Natureza, Universidade Federal da Paraíba, \\ Cidade Universitária, Castelo Branco, 58059-900 João Pessoa, PB, Brasil \\ ${ }^{2}$ Programa de Pós-Graduação em Ecologia e Recursos Naturais, Universidade Federal de São Carlos, \\ Rodovia Washington Luis km 235, Caixa Postal 676, 13565-905 São Carlos, SP, Brasil \\ ${ }^{3}$ Departamento de Ecologia e Biologia Evolutiva, Universidade Federal de São Carlos, \\ Rodovia Washington Luis km 235, Caixa Postal 676, 13565-905 São Carlos, SP, Brasil \\ Manuscript received on September 22, 2009; accepted for publication on August 2, 2010
}

\begin{abstract}
The Atlantic Forest has a high destruction rate and there is little information available on some aspects of the neotropical bird biology. Changes in environment are important factors that affect the resources available to birds. We compared the species sensitivity level of understorey birds in two areas in distinct successional stages (primary and secondary sections). Two 100 ha plots of lowland Atlantic Forest were analysed between August and December 2006. Among 25 bird species recorded, thirteen had lower abundance in secondary forest, two in primary forest, and ten had not clear tendency. According to the criteria used, the percentages for species with low, and medium and high sensitivity to habitat change were $44 \%$ and $56 \%$, respectively. The number of species was not associated with the endemism level or foraging strata. Results show the importance of knowing bird species' sensitivity level with regard to habitat modification, and not only forest fragmentation.
\end{abstract}

Key words: degradation, neotropical birds, point counts, South America, tropical forest.

\section{INTRODUCTION}

Many studies have been developed on the effects that area size or fragment isolation has on neotropical birds (Willis 1979, Bierregaard and Stouffer 1997, Boscolo et al. 2008, Lees and Peres 2008). Recently, analyses regarding to habitat modification effects on the forest birds or specific functional groups have increased (Haugaasen et al. 2003, Harris and Pimm 2004, Barlow et al. 2006), although little information is available on the Atlantic Forest (Aleixo 1999, Maldonado-Coelho and Marini 2000, Anjos 2006).

Only $11.26 \%$ of the original area covered by the Atlantic Forest - one of the richest biomes on Earth - remains (Morellato and Haddad 2000, Myers et al. 2000,

Correspondence to: Alan Loures-Ribeiro

E-mail: alan.loures@gmail.com / loures@dse.ufpb.br
Ribeiro et al. 2009). Despite the establishment of a lot of small isolated fragments, many have lost their original characteristics (Viana et al. 1997). Timber extraction, forest fires, introduction of exotic animals (cattle), and hunting are the main factors that cause this degradation (Ranta et al. 1998, Thiollay 1999, Marsden et al. 2005). Forest fragments tend to lose their capacity to harbour several sensitive species, mainly the forest specialists (Goerck 1997, Anjos 2006, Harris and Pimm 2008). Analyses of these effects on bird communities may have important uses in more efficient management and conservation activities for bird species and their respective habitats (Jones 2004).

Here, we studied the occurrence of understorey birds along two stretches of forest at different vegetation successional stages. More specifically, our objectives 
were: (1) to evaluate the encounter rates of understorey bird species in primary and secondary forests; (2) to verify whether features of life history, such as endemism or foraging strata, predict the species sensitivity in a bird group.

\section{METHODS}

\section{STUDY AREA}

The current research was undertaken in the Rio Doce State Park (RDSP), one of the largest forest reserves (ca. 36,000 ha) in the lowland Atlantic Forest, Brazil. It is located in the Marliéria municipality $\left(19^{\circ} 48^{\prime} 18^{\prime \prime}\right.$ $\left.19^{\circ} 24^{\prime} 29^{\prime \prime} \mathrm{S}, 42^{\circ} 38^{\prime} 30^{\prime \prime}-42^{\circ} 28^{\prime} 18^{\prime \prime} \mathrm{W}\right)$, in the middle of the Rio Doce basin, eastern Minas Gerais State (Fig. 1). Its vegetation coverage is composed of a seasonal semideciduous lowland forest, at different successional stages, and features a significant system of natural lakes (approximately 40 ). It is about $350 \mathrm{~m}$ high with the annual average rainfall of $1,480 \mathrm{~mm}$ and the mean annual temperature of $22^{\circ} \mathrm{C}$. The dry season is between May and September, and the rains occur from November to March (Brito et al. 1997).

The sampling was undertaken in two forest sections of 100 ha each. The first sampled plot (control area) was located in a primary forest, in which several plant species, typical of the climax stage, may be found. These species include Ficus gomelleira (Moraceae), Lecythis pisonis (Lecythidaceae), Euterpe edulis (Arecaceae), and Virola gardneri (Miristicaceae). The mean height of the forest canopy is approximately $20 \mathrm{~m}$, although emergent trees reach a height of $40 \mathrm{~m}$. The other forest section has suffered forest fires, mainly surface, ones with the last one occurring some 14 years ago. The plants found in this plot include Cecropia sp. (Cecropiaceae), Typha sp. (Typhaceae), Carex sp. (Cyperaceae), and Astrocaryum aculeatissimum (Arecaceae), which are typical of the initial successional stages. The mean height of the forest canopy is approximately $16 \mathrm{~m}$. There are plains in both plots that flood, especially in the rainy season.

\section{SAMPLING AND DATa ANALYSES}

We collected data between August and December 2006. Each plot had 36 point counts, but two points in the primary forest were lost by flooding during the rainy season. The points were spread throughout six linear transects with a spacing of $200 \mathrm{~m}$, the same distance as among the points. Each morning we collected 12 points (05h45-09h30). In total, each one of the 36 points in each forest section was sampled six times. All samples were obtained by point counts without any distance restrictions (Bibby et al. 2000). Sampling at each point lasted 10min, and all birds seen or heard were considered. Each bird was registered only once at each point. Simultaneously to the detection of the birds by the chief researcher, an assistant recorded the bird sounds with a Sony TCM 5000 recorder and a Sennheiser ME66 directional microphone. Only the understorey bird species detected, according to the criterion classification of Parker III et al. (1996), were analysed.

The Index of Point Abundance (IPA) was used as an index of relative abundance of species (Aleixo and Vielliard 1995, Anjos and Boçon 1999). The IPA was determined by dividing the total number of contacts of each species by the total number of points sampled in each forest section. This analysis method has been used broadly, especially in bird studies of the Brazilian Atlantic forest (Aleixo and Vielliard 1995, Anjos and Boçon 1999, Vielliard 2000, Anjos 2001, Anjos 2007). The use of this methodology allows us to compare the encounter rate among distinct habitats to same species, but not among distinct species (Aleixo and Vielliard 1995).

In our analyses, only the understorey birds were selected, considering mainly the habitat modification of understorey forests after the occurrence of surface fire. We also classified the species according to its sensitivity level (high, medium, and low), considering the total number of contacts in each plot, as follows: (i) high, when the species was not recorded or when its recordings were bellow $10 \%$ in disturbed areas; (ii) medium, when the recordings were between $10-30 \%$ in the disturbed plot; (iii) low, when species recordings were over $30 \%$ in the disturbed plot. This criterion follows the number of contiguous points of the secondary forest plot to the surroundings of the primary forest $(30 \%)$. Although arbitrary, we believed that $30 \%$ would be adequate to mitigate the effects of the influence of the near primary forest stretches. 


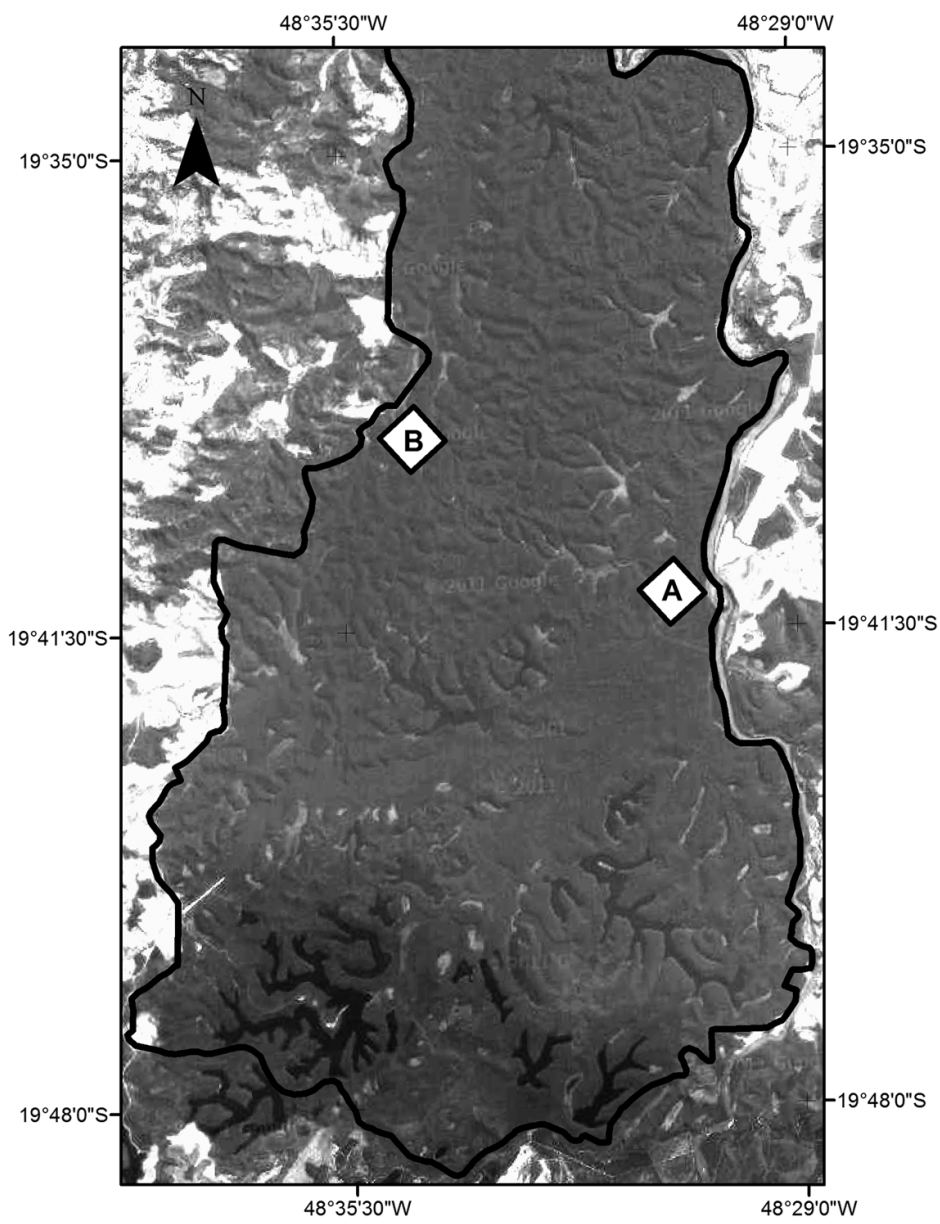

BRAZIL

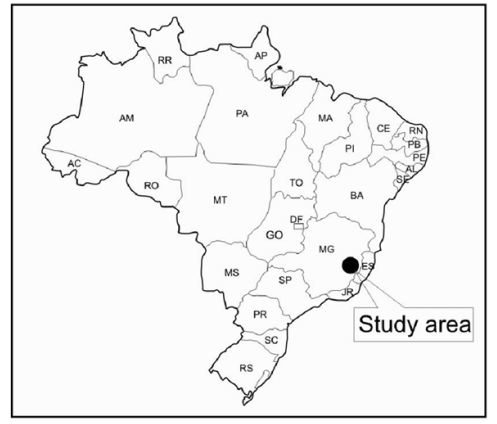

Fig. 1 - Two plots (A - primary forest plot; B - disturbed plot) of the Rio Doce State Park, Minas Gerais State, southeastern Brazil.

In the literature, we consider the high and medium sensitivity levels of species to be similar since both are more prone to extinction. So, to facilitate the comparisons with other authors, we grouped the two classifications (high and medium levels). Data on endemism, foraging strata and conservation priority level followed Parker III et al. (1996). The threat level of the species was based on the "List of threatened species in Minas Gerais State" (Fundação Biodiversitas 2008), and on the Red List of the International Union for Conservation of Nature (IUCN 2008).

We tested the null hypothesis of no difference in the contacts number of the species between the primary and secondary forests by G-test $(P<0.05)$. We also verified whether the endemism level or foraging strata affected species sensitivity in the two different successional stages. Species were thus divided into two groups (high/medium versus low sensitivities). Whereas the G-test was employed for all comparisons $(P<0.05)$, the Williams correction factor was used to obtain the adjusted G-value (Fowler et al. 1998). Only species with " $n$ " higher than five were compared in the abovementioned analyses, coupled to at least one individual in the two plots.

\section{RESULTS}

A total of twenty-five understorey bird species were recorded in the present study, totalling 935 contacts (Appendix). Moreover, 32\% showed high and medium conservation priority levels, and three species (Crypturellus noctivagus, Dysithamnus plumbeus and Neopelma aurifrons) were highlighted as presenting a very high level. Of all detected understorey species, six are threatened in regional or global lists (Tinamus solitarius, Crypturellus noctivagus, Odontophorus capueira and Schiffornis turdina, regional list; Dysithamnus plumbeus and Neopelma aurifrons, global list). 
Fifteen out of twenty-five sampled species occurred in different proportions in the two plots. In fact, thirteen species had the lowest IPA in the disturbed area, namely, Tinamus solitarius, Baryphthengus ruficapillus, Dysithamnus plumbeus, Neopelma aurifrons, Drymophila squamata and Dendrocincla turdina. Two species, Penelope superciliaris and Lathrotriccus euleri, were more frequent in the disturbed plot. No significant differences occurred among other species with regard to IPA between the plots, or they could not be compared due to the low number of detected individuals (see Appendix).

About $56 \%$ of species had high and medium sensitivity, whereas $44 \%$ showed low sensitivity. Endemic species did not show higher sensitivity to the secondary forest than the non-endemic $(G=0.951$; df $=1 ; P>$ $0.05)$. No relationship has been established among the foraging strata of species and their response to the distinct successional stages $(G=0.319 ; \mathrm{df}=2 ; P>0.05)$.

\section{DISCUSSION}

Human disturbances cause serious damage to the forest biota (Laurance et al. 1997). Changes in the original characteristics of forest remnants in the Atlantic Forest affect the richness and composition of the bird community, especially insectivorous and understorey bird species (Aleixo 1999, Maldonado-Coelho and Marini 2000). Furthermore, increases in forest edge areas change the movements of the understorey birds, especially of those living in their interior (Hansbauer et al. 2008), which then tend to avoid forest edges and clearings. Laurance et al. (2004) have also detected changes in the avifauna movement next to roads in the Amazon region. Forest-dependent insectivorous birds, mixed bird flocks, some solitary terrestrial species and understorey birds were the most affected.

Our data suggest that changes in local conditions may have been preponderant concerning the distribution of some birds. Many bird species are intolerant to high levels of light and tend to avoid edge areas (Laurance et al. 2004). In our study area, terrestrial species, such as $T$. solitarius, $C$. noctivagus and $O$. capueira, were only found in the forest interior, and, even so, not in forest clearings. Moreover, typical understorey species, such as D. plumbeus, D. squammata and S. turdina, may have a preference for areas with low light levels. Among Amazonian understorey birds, factors, such as the evolutionary history of species, structural change of environment and traffic-related disturbances, are determinants of edge avoidance (Laurance et al. 2004). Regarding the two woodcreeper species (D. turdina and $X$. fuscus), both showed the lowest number of contacts in the area of the disturbed forest coinciding with the northern Paraná (Poletto et al. 2004, Anjos 2006). However, $X$. fuscus did not show the same sensitivity level (low sensitivity) in the upper of the Rio Doce basin (Ribon et al. 2003).

Forest fires may also greatly affect fauna and flora (Barlow and Peres 2004). Studies undertaken in the Amazon region have reported that terrestrial and understorey birds are highly affected by them (Peres et al. 2003, Barlow et al. 2006). In our case, a forest fire in the 1990 s caused habitat modification in the area under analysis. The low IPA of some bird species may have occurred due to initial successional stages; thus, several forest specialist species and/or specific functional groups may be more vulnerable to the habitat modification. Moreover, the effects of a forest fire may be prolonged for a longer period of time since these environments undergo a gradual process of recovery. While these arguments may have some validity, we have no data prior to the occurrence of fires in the area. Thus, any attempt to relate the changes in the habitat to fire would be unfortunately speculative.

Although current data are not related to some aspects of forest fragmentation (e.g., isolation or edge effects), bird species similar to those from other areas had the same response to environmental change. In the upper Rio Doce (Ribon et al. 2003), for instance, ten out of thirteen common species in our investigation were relatively similar regarding their sensitivity levels. Three species (T. solitarius, O. capueira and D. turdina) were considered extinct in the upper Doce River areas, and have been classified as of medium sensitivity in our study area. No similarity of sensitivity occurred in another three species (G. montana, M. rufiventris and $X$. fuscus). Marsden et al. (2001) studied thirty-one forest fragments in the southeast of Brazil. Although these authors did not use the same methodology of this research, we understand that species detected exclusively in the 
Linhares Forest Reserve ( $c a$. 40,000 ha) can be classified as extremely sensitive. Nine out of thirteen species registered in the middle Doce River were also similar to our results.

In most cases, the process of environmental modification may be less drastic than that related to habitat loss (Turner 1996). Furthermore, the greater the forest remnants, the higher the chances of conservation of viable populations (MacArthur and Wilson 1967, Marsden et al. 2005). In this case, it is expected that the current sensitivity levels of the species are less drastic when compared with those related to fragmented areas and with different degrees of isolation. In spite of the above, sensitivity levels of certain terrestrial and understorey bird species showed an average concordance rate of over $69 \%$ with the level converted from Marsden et al. (2001), Ribon et al. (2003), Anjos (2006) and Uezu (2006).

Anjos (2006) contrasted the sensitivity of seventyfive species between an area of Paraná State, southern Brazil, and another in Minas Gerais, southeastern Brazil. This study suggested that the location of species within their geographical distribution area may be determinant concerning the differences in their vulnerability. However, regional characteristics may greatly affect biological communities (Laurance et al. 1997, Ribon et al. 2003). For instance, current data indicate low sensitivity for P. superciliaris, which is very similar to the level found by Anjos (2006) in the northern region of Paraná State, and by Uezu (2006) in the western region of São Paulo State. However, in the upper Rio Doce, about $100 \mathrm{~km}$ from our area, this species was considered critically endangered (Ribon et al. 2003) probably due to hunting activities. Reports on the hunting of $P$. superciliaris have arisen in unprotected areas along the middle course of the Rio Doce.

Species sensitivity indexes may also be related to ecological and evolutionary factors (Goerck 1997), such as endemism (Ribon et al. 2003) or ecological similarities among species (Gray et al. 2007). Nevertheless, no association between endemism or foraging strata and the abundance index was found. Anjos (2006) has also observed a weak relation between sensitivity level and foraging strata.

Although the RDSP has an efficient fire-fighting system, it has become necessary to pay more attention to this disturbance. In fact, the RDSP is one of the last well-preserved conservation units in the Brazilian lowland Atlantic Forest. Our results show the importance of habitat conservation for some understorey bird species of the Brazilian Atlantic forest. Although there are protected areas at the government, the effective preservation of these areas is essential. Fires, illegal timber extraction, hunting, and other disturbances are a threat to the local biodiversity not only in unprotected areas, but also in areas that are Conservation Units.

\section{ACKNOWLEDGMENTS}

The authors would like to thank many colleagues who gave important contributions to the manuscript. $\mathrm{N}$. Gobbi, P.F. Develey, O. Rocha, J.R. Verani, and two anonymous reviewers discussed some of our ideas. A. Hirsch helped us with the map of the study area. Our considerations to the Instituto Estadual de Florestas de Minas Gerais (IEF-MG) for granting authorization to work in the area. The current research was funded by the Center for Applied Biodiversity Science of the Conservation International, and by the Gordon \& Betty Moore Foundation through the TEAM (Tropical Ecology, Assessment and Monitoring) Program.

\section{RESUMO}

A Floresta Atlântica apresenta uma alta taxa de destruição e pouca informação disponível de alguns aspectos da biologia da avifauna neotropical. Alterações do ambiente são fatores importantes que influenciam nos recursos disponíveis para as aves. Nós comparamos o nível de sensibilidade das espécies de aves do sub-bosque de dois trechos em diferentes estágios sucessionais (trechos de floresta primária e secundária). Dois trechos de 100 ha cada de Floresta Atlântica de baixada foram analisados entre agosto e dezembro de 2006. Entre as 25 espécies de aves analisadas, treze tiveram menor abundância no trecho de floresta secundária, duas na floresta primária, e dez não mostraram qualquer tendência. De acordo com os critérios adotados, as porcentagens de espécies que apresentaram sensibilidades baixa, e média e alta às alterações de habitat foram de $44 \%$ e $56 \%$, respectivamente. O número de espécies afetadas não esteve associado ao grau de endemismo ou estrato de forrageamento. Os resultados indicam a importância do conhe- 
cimento do grau de sensibilidade das espécies de aves quanto à modificação dos habitats e não apenas aos efeitos da fragmentação florestal.

Palavras-chave: degradação, aves neotropicais, pontos de escuta, América do Sul, floresta tropical.

\section{REFERENCES}

AlEIXO A. 1999. Effects of selective logging on a bird community in the Brazilian Atlantic forest. Condor 101: 537-548.

AleiXo A AND Vielliard JME. 1995. Composição e dinâmica da avifauna da mata de Santa Genebra, Campinas, São Paulo, Brasil. Rev Bras Zool 12: 493-511.

ANJOS L DOS. 2001. Bird communities in five Atlantic forest fragments in southern Brazil. Orn Neotr 12: 11-27.

ANJos L DOS. 2006. Bird species sensitivity in a fragmented landscape of the Atlantic forest in southern Brazil. Biotropica 38: 229-234.

ANJos L Dos. 2007. A eficiência do método de amostragem por pontos de escuta na avaliação da riqueza de aves. Rev Bras Ornitol 15: 239-243.

ANJos L DOS AND BoçON R. 1999. Bird communities in natural forest patches in southern Brazil. Wilson Bull 111: 397-414.

BARlow J AND Peres CA. 2004. Ecological responses to El Niño-induced surface fires in central Brazilian Amazonia: management implications for flammable tropical forests. Phil Trans R Soc Lond B 359: 367-380.

Barlow J, Peres CA, Henriques LMP, Stouffer PC AND Wunderle JM. 2006. The responses of understorey birds to forest fragmentation, logging and wildfires: An Amazonian synthesis. Biol Conserv 128: 182-192.

Bibby CJ, Burgess ND, Hill DA and Mustoe SH. 2000. Bird census techniques. Second Edition. Academic Press, USA, 302 p.

BierregaArd RO JR AND StoufFer PC. 1997. Understory birds and dynamic habitat mosaics in Amazonian rainforests. In: LAURANCE WF AND BIERREGAARD RO JR (Eds), Tropical forest remnants: ecology, management, and conservation of fragmented communities, Chicago: University of Chicago Press, Chicago, USA, p. $138-155$.

Boscolo D, Candia-Gallardo C, Awade M and METZGER JWP. 2008. Importance of interhabitat gaps and stepping-stones for Lesser Woodcreepers (Xiphorhynchus fuscus) in the Atlantic forest, Brazil. Biotropica 40: 273-276.
Brito FRA, Oliveira AMHC AND JUnQueira AC. 1997. A ocupação do território e a devastação da Mata Atlântica. In: PAULA JA (Ed), Biodiversidade, População e Economia - Uma Região de Mata Atlântica, PADCTCIAMB/UFMG-CEDEPLAR-ECMVS, Belo Horizonte: Rona Editora, Belo Horizonte, Brasil, p. 49-90.

Fowler J, Cohen L AND JARVIS P. 1998. Practical statistics for field biology. J Wiley \& Sons, West Susex, UK, $258 \mathrm{p}$.

FUNDAÇÃo BIOdIVERSITAS. 2008. Revisão das listas das espécies da flora e da fauna ameaçadas de extinção do Estado de Minas Gerais. Relatório Técnico Final. Volume 3. Belo Horizonte: Fundação Biodiversitas, Brasil, p. 104-142.

GoerCK J. 1997. Patterns of rarity in the birds of the Atlantic Forest of Brazil. Conserv Biol 11: 112-118.

Gray MA, Baldauf SL, Mayhew PJ And Hill JK. 2007. The response of avian feeding guilds to tropical forest disturbance. Conserv Biol 21: 133-141.

Hansbauer MM, Storch I, Leu S, Nieto-Holguin J-P, Pimentel RG, Knauer P And Metzger JPW. 2008. Movements of neotropical understory passerines affected by anthropogenic forest edges in the Brazilian Atlantic rainforest. Biol Conserv 141: 782-791.

HARRIS G AND PIMM L. 2004. Birds species' tolerance of secondary forest habitats and its effects on extinction. Conserv Biol 18: 1607-1616.

HARRIS G AND PIMM SL. 2008. Range size and extinction risk in forest birds. Conserv Biol 22: 163-171.

Haugaasen T, Barlow J And Peres CA. 2003. Effects of surface fires on understorey insectivorous birds and terrestrial arthropods in central Brazilian Amazonia. Anim Conserv 6: 299-306.

IUCN 2008. 2008 IUCN Red List of Threatened Species. $<$ www.iucnredlist.org > . Downloaded on 11 March 2009.

JONES CG. 2004. Conservation management of endangered birds. In: Sutherland WJ, Newton I AND GREeN RE (Eds), Bird ecology and conservation: A handbook of techniques, New York: Oxford University Press, New York, p. 269-301.

Laurance SGW, Stouffer PC And Laurance WF. 2004. Effects of road clearings on movement patterns on the understory rainforest birds in Central Amazonia. Conserv Biol 18: 1099-1109.

LAURANCE WF ET AL. 1997. Tropical forest fragmentation: Synthesis of a diverse and dynamic discipline. In: LAURANCE WF AND BIERREGAARd RO JR (Eds), Tropical forest remnants: ecology, management, and conserva- 
tion of fragmented communities, Chicago: University of Chicago Press, Chicago, USA, p. 502-514.

LeEs AC AND PEREs CA. 2008. Avian life-history determinants of local extinction risk in a hyper-fragmented neotropical forest landscape. Animal Conserv 11: 128137.

MacARThur RH And Wilson EO. 1967. The Theory of Island Biogeography. Princeton University Press, 203 p.

MaldonAdo-COElHo M AND MARINI MÂ. 2000. Effects of forest fragment size and successional stage on mixedspecies bird flocks in southeastern Brazil. Condor 102: 585-594.

Marsden SJ, Whiffin M And Galetti M. 2001. Bird diversity and abundance in forest fragments and Eucalyptus plantations around an Atlantic forest reserve, Brazil. Biodiv Conserv 10: 737-751.

Marsden SJ, Whiffin M, Galetti M And Fielding A. 2005. How well Brazil's system of Atlantic forest reserves maintain viable bird populations? Biodiv Conserv 14: 2835-2853.

MOREllato LPC AND HADDAD CFB. 2000. Introduction: The Brazilian Atlantic forest. Biotropica, p. 786-792.

Myers N, Mittermeier RA, Mittermeier CG, FonSECA GAB AND KENT J. 2000. Biodiversity hotspots for conservation priorities. Nature 403: 853-858.

PARker TA III, Stotz DF AND FitzPATrick JW. 1996. Ecological and Distributional Databases. In: STOTZ DF, FitzPATRICK JW, PARKER TA III AND MOSKOVITS DK (Eds), Neotropical Birds: Ecology and Conservation, Chicago: The University of Chicago Press, Chicago, USA, p. 115-191.

Peres CA, Barlow J And Haugaasen T. 2003. Vertebrate responses to surface wildfires in a central Amazonian forest. Oryx 37: 97-109.

Poletto F, Anjos L dos, Lopes EV, Volpato GH, SERAFINI PP AND FAVARO FL. 2004. Caracterização do microhabitat e vulnerabilidade de cinco espécies de arapaçus (Aves: Dendrocolaptidae) em um fragmento florestal do norte do estado do Paraná, sul do Brasil. Ararajuba 12: 89-96.
Ranta P, Blom T, Niemela J, JoensuU E AND SiItonen M. 1998. The fragmented Atlantic rain forest of Brazil: Size, shape and distribution of forest fragments. Biodiv Conserv 7: 385-403.

Ribeiro MC, Metzger JP, Martensen AC, Ponzoni FJ AND HiRota MM. 2009. The Brazilian Atlantic forest: How much is left, and how is the remaining forest disturbed? Implications for conservation. Biol Conserv 142: 1141-1153.

Ribon R, Simon JE And Mattos GT. 2003. Bird extinctions in Atlantic Forest fragments of the Viçosa Region, southeastern Brazil. Conserv Biol 17: 1827-1839.

Thiollay J-M. 1999. Responses of an avian community to rain forest degradation. Biodiv Conserv 8: 513-534.

TURNER IM. 1996. Species loss in fragments of tropical rain forest: a review of the evidence. J Applied Ecol 33: 200-209.

UEZU A. 2006. Composição e estrutura da comunidade de aves na paisagem fragmentada do Pontal do Paranapanema. PhD. Thesis. Universidade de São Paulo, São Paulo, Brasil.

Viana VM, TABAnez AAJ And Batista JLF. 1997. Dynamics and restoration of forest fragments in the Brazilian Atlantic moist forest. In: LAURANCE WF AND BIERREGAARD RO JR (Eds), Tropical forest remnants: ecology, management, and conservation of fragmented communities, Chicago: University of Chicago Press, Chicago, USA, p. 351-365.

VIELLIARD JME. 2000. Bird community as an indicator of biodiversity: results from quantitative surveys in Brazil. An Acad Bras Cienc 72: 323-330.

WILLIS EO. 1979. The composition of avian communities in remanescent woodlots in southern Brazil. Papéis Avulsos Zool 33: 1-25. 
APPENDIX

Number of detections (n), Index of Point Abundance (IPA), sensitivity level (S), endemism (End) and foraging strata (FOR) of twenty-five terrestrial and understorey bird species of a stretch of the lowland Atlantic Forest, southeastern Brazil.

\begin{tabular}{|c|c|c|c|c|c|c|}
\hline \multirow{2}{*}{ Species } & \multicolumn{2}{|c|}{$\mathrm{IPA}^{\mathrm{a}}$} & \multirow{2}{*}{$\mathrm{S}^{\mathrm{b}}$} & \multirow{2}{*}{ End } & \multirow{2}{*}{$\mathrm{FOR}^{\mathrm{c}}$} & \multirow{2}{*}{$G$-test $\mathrm{d}^{\mathrm{d}}$} \\
\hline & $\mathrm{PF}$ & $\mathrm{SF}$ & & & & \\
\hline Tinamus solitarius & 0.111 & 0.018 & medium & yes & $\mathrm{T}$ & $<0.001$ \\
\hline Crypturellus obsoletus & 0.171 & 0.064 & medium & no & $\mathrm{T}$ & $<0.001$ \\
\hline Crypturellus noctivagus & 0.638 & 0.055 & high & yes & $\mathrm{T}$ & $<0.001$ \\
\hline Penelope superciliaris & 0.037 & 0.083 & low & no & $\mathrm{T}$ & 0.049 \\
\hline Odontophorus capueira & 0.064 & 0.013 & medium & yes & $\mathrm{T}$ & 0.006 \\
\hline Aramides saracura & 0.013 & 0.041 & low & yes & $\mathrm{T}$ & 0.082 \\
\hline Geotrygon montana & 0.111 & 0.111 & low & no & $\mathrm{T}$ & - \\
\hline Glaucis hirsutus & - & 0.018 & low & no & $\mathrm{U}$ & - \\
\hline Phaethornis idaliae & 0.148 & 0.190 & low & yes & $\mathrm{U}$ & 0.293 \\
\hline Phaethornis ruber & - & 0.027 & low & no & $\mathrm{U}$ & - \\
\hline Baryphthengus ruficapillus & 0.236 & 0.041 & medium & yes & UM & $<0.001$ \\
\hline Dysithamnus plumbeus & 0.175 & 0.055 & medium & yes & $\mathrm{U}$ & $<0.001$ \\
\hline Myrmotherula axillaris & 0.148 & 0.190 & low & no & UM & 0.198 \\
\hline Drymophila squamata & 0.055 & 0.004 & high & yes & $\mathrm{U}$ & 0.001 \\
\hline Conopophaga melanops & 0.083 & 0.018 & medium & yes & $\mathrm{U}$ & 0.002 \\
\hline Dendrocincla turdina & 0.120 & 0.037 & medium & yes & UM & 0.001 \\
\hline Xiphorhynchus fuscus & 0.092 & 0.013 & medium & yes & UM & 0.001 \\
\hline Automolus leucophthalmus & 0.083 & 0.083 & low & yes & $\mathrm{U}$ & - \\
\hline Xenops minutus & 0.037 & 0.013 & medium & no & UM & 0.133 \\
\hline Mionectes rufiventris & 0.013 & 0.023 & low & yes & UM & 0.490 \\
\hline Leptopogon amaurocephalus & - & 0.037 & low & no & UM & - \\
\hline Lathrotriccus euleri & 0.078 & 0.260 & low & no & $\mathrm{U}$ & $<0.001$ \\
\hline Neopelma aurifrons & 0.185 & 0.070 & medium & yes & $\mathrm{U}$ & $<0.001$ \\
\hline Schiffornis turdina & 0.130 & 0.051 & medium & no & $\mathrm{U}$ & 0.005 \\
\hline Habia rubica & 0.064 & 0.004 & high & no & UM & $<0.001$ \\
\hline
\end{tabular}

${ }^{\mathrm{a}}$ Index of Point Abundance in the: PF - Primary Forest; SF - Secondary Forest. ${ }^{\mathrm{b}}$ Sensitivity (see Methods). ${ }^{\mathrm{c}}$ Strata Foraging: U - Understorey; UM - Understorey/Midstory; T - Terrestrial. ${ }^{\mathrm{d}}$ Significance level. 